\title{
Food Politics
}

\author{
Matthew N. O. Sadiku', Tolulope J. Ashaolu², Sarhan M. Musa1
}

\author{
${ }^{1}$ Roy G. Perry College of Engineering, Prairie View A\&M University, Prairie View, Texas \\ ${ }^{2}$ College of Food Science, Southwest University, Tiansheng Road Beibei District, Chongqing, China
}

\begin{abstract}
Food politics refers to the social relations that impact the production, distribution and consumption of food. It has become a part of the popular consciousness in the last two decades. The use of food in performance is a means of engaging public consciousness and addressing American food politics. This paper provides a brief introduction to food politics.
\end{abstract}

KEYWORDS: politics, alternative food initiatives, food safety, food industries

\section{INTRODUCTION}

The production, distribution, and consumption of food are basic to our society. Food is central to the debates on the environment, economic development, trade, and globalization. Food production has become less and less a foundational institution of societies, and more and more a tenuous component of corporate globalization. The global coordination of various production sites for a supply of fresh produce is achieved through information technologies. Food has become a market that is exploited by the corporate pursuit of profit.

Concerns with food safety and with the ethics of food production and consumption have been part of social and political movements motivated by food activists. The major supermarkets have been criticized by the public, media, farmers and suppliers for their effective duopoly [1]. The rise of so-called green consumption has brought with it questions about its relationship to political action. Political consumption individualizes responsibility for environmental degradation. Government policies on food production, distribution, and consumption influence the cost, availability, and safety of the food supply.

\section{CONCEPT OF FOOD POLICTICS}

Conventional food production processes are unsustainable in social and economic terms. These production processes yield food products that raise concerns about food safety and human health [2]. The sales of organic and local food--each with its own political agenda--are growing fast. Local should not be seen as an alternative to globalization, but as an intrinsic part of it. Organic food advocates claim that organic food is better for the environment than the conventionally farmed type. Critics dispute this claim. There is no clear evidence or justification that conventional food is harmful or that organic food is nutritionally better. For example, WalMart now sells organic food and offers locally grown produce. Numerous efforts have been made to reconnect people with sustainably grown food. A number of civil groups are concerned about the impact of food price volatility on hunger. One of these efforts is Worldwide Opportunities on Organic Farms (WWOOF), which was founded in 1971. WWOOF is a progressive embodiments of food politics [3].

The contemporary food politics has roots in early protest on processed or industrialized foods and the back-to-the-land movement in 1960s. The popularization of food politics is a response to the fears of food contaminants and obesity epidemic. As a result, many conventional growers have converted to organic [4].

The corporate food industry is driven by the relentless pursuit of profit. It uses its vast economic power to fight any professional message that might conflict with the industry's determination to sell more of its products. The powerful vested interests of food industry influence nutrition and health, sometimes to the detriment of public health interests. Food politics often involves lobbying, marketing, public relations, advertising, and sponsorship arrangements, and developing relationships among certain government committees, bureaucrats, food manufacturers, and professional organizations [5].

Food security is political. Food security represents a major indicator of economic and health disparities. Education, gender, technology adoption, land quality, and income are important variables affecting food security. Other factors include population growth, environmental change, globalization, urbanization, food sovereignty, and demographic patterns [6]. More inclusive food security policies will require attention to the voices of regular people.

\section{POLITICAL EATERS}

Food choices are not just personal, but political in nature. A political eater is someone who aligns his eating habits with the social and political issues deemed important such protection of environment and animals. Politicized diets in the US include [7]:

$>$ Only organic, chemical-free foods

$>$ Only local foods

$>$ Only whole foods, not excessively processed

$>$ Only fruits, vegetables, grains, and eggs (vegetarian)

$>$ Only raw fruits, vegetables, nuts, and seeds

$>$ Only "slow foods" that are local.

Other choices include Halal foods and Kosher foods. Consumer choice figures prominently in contemporary food politics.

Junk food politics is politics devoid of policy or civic virtue. Junk food is unhealthy in diets and in politics. Americans are increasingly obsessed with the need to be healthy. We are addicted in food and politics to cheap and easy solutions. 


\section{ALTERNATIVE FOOD INITIATIVES}

There is growing concern that the current industrial food system has contributed to serious challenges for populations around the globe and has failed to equitably meet people's need. Various alternative food initiatives (AFIs) have emerged to challenge this corporate-led. AFIs aim to challenge the corporate-led, industrial food system by attempting to develop viable localized solutions. Increasing interest in food issues has led to the expanding number of AFIs across North America [8].

The following typology can be used to conceptualize the scope of AFIs [8]:

$>$ Social justice initiatives address power and material equity.

$>$ Ecological sustainability initiatives address the connection between human and ecological systems.

$>$ Community health initiatives address regional capacity to produce and distribute adequate nutritious, safe and culturally acceptable foods.

$>$ Democracy-enhancing initiatives address process equity through increasing opportunities for public participation in decision-making.

\section{CONCLUSION}

Food politics is a controversial issue. There is no question that the United States has commercial influence over countries that depend on American food. The politics of food in the next ten years will be a matter not of power but of the economic issues, from prices and reserves to export promotion. More information about food politics can be found in books in [5,9-17].

\section{REFERENCES}

[1] M. Phillipov, "The new politics of food: Television and the media/food industries," Media International Australia, vol. 158, no. 1, 2016, pp. $90-98$.

[2] E. M. Harris, "Eat local? Constructions of place in alternative food politics," Geography Compass, vol. 4, 2010, pp. 355-369.

[3] T. Holtwick, "Sowing seeds of civic agriculture: WWOOF as in incubator of embodied food politics," Masters Thesis, University of Colorado at Colorado Springs,2016.
[4] C. M. Duffly, "From farm to table to stage: Performing food politics," Doctoral Dissertation, University of California, Berkeley, 2011.

[5] M. Nestle, Food Politics: How the Food Industry Influences Nutrition and Health. Berkeley, CA: University of California Press, 2003.

[6] M. N. O. Sadiku, S. M. Musa, and O. S. Musa, "Food security," Invention Journal of Research Technology in Engineering and Management, vol. 2, no. 7, July 2018, pp. 16-19.

[7] C. Chuck, S. A. Fernandes, and L. L. Hyers. "Awakening to the politics of food: Politicized diet as social identity," Appetite, vol. 107, 2016, pp. 425-436.

[8] C. Z. Levkoe, "Towards a transformative food politics," Local Environment, vol. 16, no. 7, 2011, pp. 687-705.

[9] E. Rothschild, "Food politics," Foreign Affairs, vol. 54, 1976. pp. 285-307.

[10] C. Fowler and P. Mooney, Shattering: Food, Politics, and The Loss of Genetic Diversity. Tucson, AZ: The University of Arizona Press, 1990.

[11] C. F. Helstosky, Garlic and Oil: Food and Politics in Italy. New York: Oxford University Press, 2004.

[12] R. Paarlberg, Food Politics: What Everyone Needs to Know. New York: Oxford University Press, 2013.

[13] M. S. Carolan, Embodied Food Politics. London, UK: Imprint Routledge, 2011.

[14] C. Lavin, Eating Anxiety: The Perils of Food Politics. University of Minnesota Press, 2013.

[15] M. K. Goodman and C. Sage, Food Transgressions: Making Sense of Contemporary Food Politics. Oxon, UK: Routledge, 2014.

[16] A.. Flammang, The Taste for Civilization: Food, Politics, and Civil Society. Urbana and Chicago: University of Illinois Press, 2009.

[17] C. Biltekoff, Eating Right in America: The Cultural Politics of Food and Health. Durham, NC: Duke University Press. 2013. 